\title{
PERAN KOPERASI SYARIAH SEBAGAI PUSAT KEGIATAN MUAMALAH JAMAAH MASJID (Studi Kasus Koperasi Syariah Baitul Mu'min Komplek Pasir Jati, Desa Jati Endah Kecamatan Cilengkrang Kabupaten Bandung)
}

\author{
Intan Nurrachmi \\ Universitas Islam Bandung \\ Jl. Tamansari No. 20, Bandung 40116 \\ Email: intannurrachmi@gmail.com \\ Setiawan \\ Politeknik Negeri Bandung \\ Jl. Gegerkalong Hilir, Desa Ciwaruga, Bandung 40012 \\ E-mail: setiawan@polban.ac.id
}

\begin{abstract}
Besides building and developing the socio-economic potential of members and society, Islamic cooperatives are also the center of muamalah activities in an effort to realize and develop a national economy based on the principles of family and economic democracy. The widespread practice of usury especially in the case of borrowing and investing, and an economy dominated by large companies, makes difficulty for small traders to develop and compete. This resulted in lower economic levels of society. Islamic cooperatives have great potential both in terms of human resources and other supporters. This study examines the role of the Baitul Mu'min Syariah cooperative in reducing the practice of usury and developing the welfare of the Ummah. This is a qualitative research that combines library research and filed research with an empirical approach. The results showed that the Baitul Mu'min Sharia cooperative was established to improve ukhuwah Islamiyah, the spirit of mutual cooperation and help, and to improve the welfare and prosperity of the congregation. It has contributed greatly to the service of the needs of its members and has improved the economy of its members, who are mostly worshipers of the Baitul Mu'min mosque.
\end{abstract}

Keywords: Islamic Cooperatives, Muamalah, Ukhuwah Islamiyah, Mutual Cooperation

\begin{abstract}
Abstrak: Peran koperasi syariah di antaranya adalah membangun dan mengembangkan potensi dan kemampuan anggota pada khususnya, dan masyarakat pada umumnya, guna meningkatkan kesejahteraan sosial ekonominya. Selain itu, koperasi syariah bisa berperan sebagai pusat kegiatan muamalah dalam usaha mewujudkan dan mengembangkan perekonomian nasional yang berdasarkan azas kekeluargaan dan demokrasi ekonomi. Maraknya praktek riba dalam bermuamalah terutama dalam hal pinjam-meminjam maupun dalam investasi, dan perekonomian didominasi oleh perusahaan-perusahaan besar, menyebabkan para pedagang kecil sulit berkembang dan bersaing. Hal tersebut mengakibatkan taraf ekonomi masyarakat semakin rendah. Koperasi syariah mempunyai potensi yang besar baik dari segi sumber daya manusia maupun pendukung lainnya, namun masih banyak koperasi Syariah yang belum maksimal dalam pengelolaannya. Hasil dari penelitian ini menunjukkan bahwa koperasi Syariah Baitul Mu’min didirikan bertujuan untuk meningkatkan ukhuwah Islamiyah, semangat gotong royong dan tolong menolong, serta meningkatkan kesejahteraan dan kemakmuran jamaah. Selama ini, koperasi syariah tersebut telah banyak berkontribusi dalam pelayanan kebutuhan anggotanya serta meningkatkan perekonomian para anggotanya yang sebagian besar merupakan jamaah masjid Baitul Mu’min.
\end{abstract}

Kata kunci: Koperasi Syariah, Muamalah, Ukhuwah Islamiyah, Gotong Royong

\section{Pendahuluan}

Masjid adalah tempat yang multi fungsi bagi umat Islam di seluruh dunia. Bahkan pada zaman Rasulullah saw, masjid merupakan pusat dari segala kegiatan ummat. Namun, peran masjid di masa sekarang tampaknya lebih terkonsentrasi pada kegiatan yang bersifat ritualistik dan pendidikan. Padahal selain memiliki fungsi inti 
sebagai tempat berjamaah, pusat pengajaran Islam dan membaca Alquran, masjid juga dapat melakukan fungsi-fungsi lain seperti pusat administrasi, pusat komunitas, pusat belajar dan pusat ekonomi. ${ }^{1}$ Bila dicermati, perihal muamalah menghabiskan lebih banyak waktu dibanding dengan urusan ibadah, sehingga waktu tersebut harus lebih banyak dimanfaatkan dengan baik.

Muamalah di dalam ajaran Islam menurut Suhendi merupakan peraturan-peraturan Allah yang mengatur hubungan antara manusia dengan manusia lainnya dalam hal cara mendapatkan dan mengembangkan harta benda. ${ }^{2}$ Ruang lingkup muamalah ada yang bersifat adabiyah dan madiyah, yang bersifat adabiyah adalah ijab dan kabul, saling meridhai, tidak terdapat keterpaksaan antara semua pihak, hak dan kewajiban, kejujuran pedagang, penipuan, pemalsuan, penimbunan, dan segala hal yang dihasilkan indera manusia yang berkaitan dengan peredaran harta benda dalam hidup bermasyarakat. Sedangkan yang bersifat madiyah adalah masalah jual-beli, gadai, jaminan dan tanggungan, pemindahan hutang, perseroan atau perkongsian, sewa-menyewa, upah dan lain sebagainya.

Berikut beberapa pihak yang terlibat dalam muamalah sebagai contoh dalam jual beli ada yang berperan sebagai penjual dan ada yang menjadi pembeli. Di dalam ajaran Islam kedua pihak yang melakukan mu'amalah ini harus memenuhi syarat sesuai yang digariskan dalam Alquran dan hadis serta ijma para ulama. Begitupun dalam prakteknya di atur agar terhindar dari praktek-praktek yang diharamkan seperti terjadinya Riba. Tentunya karena riba akan merugikan sebelah pihak ataupun kedua belah pihak, karena di dalam ajaran Islam tidak diperbolehkan praktek muamalah yang

1 Fidlizan, M., Mohd Yahya, M.H., Azila, A.R., \& Fatimah Salwa, A.H., "Persepsi Masyarakat Islam Terhadap Ide Pendanaan Dana Masjid: Kajian di Perak", Sains Humanika, Vol. 2, No. 1, 2014, h. 101.

${ }^{2}$ Hendi Suhendi, Fiqih Muamalah, (Jakarta: RajaGrafindo Persada, 2002), h. 2. mengandung unsur gharar ataupun perbuatan keji.

Kegiatan untuk mempermudah dalam melakukan muamalah diperlukan adanya komunitas atau badan usaha yang bisa memenuhi segala macam kebutuhan baik itu kebutuhan sandang, papan maupun pangan. Meskipun begitu banyak badan usaha yang bisa memenuhi kebutuhan itu namun biasanya menghadapi beberapa kendala di antaranya jarak yang jauh, harga yang mahal ataupun kualitas barang yang belum diketahui baik buruknya. Untuk mengatasi masalah tersebut maka dibutuhkan adanya badan usaha yang dekat jaraknya, terjangkau harganya, terbukti baik kualitasnya dan kalau bisa memberikan keuntungan bagi para pembelinya.

Koperasi merupakan salah satu bentuk kerja sama dalam bidang usaha yang diharapkan bisa menjadi salah satu jalan keluar bagi permasalahanpermasalahan yang dihadapi dalam bermu'amalah sebagaimana disampaikan sebelumnya. Tentunya bukan hal yang mudah menjadikan koperasi sebagai salah satu jalan keluar untuk menyelesaikan permasalahan tersebut karena koperasi akan bersaing dengan Mall, super market bahkan mini market yang sudah tersebar luas sampai ke pelosok. Dibutuhkan komitmen yang kuat agar koperasi bisa bersaing dengan badan usaha yang lebih besar dan didukung modal yang besar. Untuk itu para tokoh yang terlibat dalam badan usaha koperasi tersebut harus mempunyai kemampuan dan kemauan untuk mengembangkan dan memajukan koperasi tersebut. Ketika koperasi menjadi tujuan prioritas dalam melakukan mu'amalah maka koperasi tersebut telah menjadi pusat kegiatan mu'amalah bagi para anggotanya maupun masyarakat sekitarnya. Asas usaha Koperasi Syariah berdasarkan konsep gotong royong dan tidak dimonopoli oleh salah satu pemilik modal. Begitu pula dalam hal keuntungan yangdiperoleh maupun kerugian yang diderita harus dibagi secara sama dan proporsional. ${ }^{3}$

${ }^{3}$ Nur S. Buchori, Koperasi Syariah, (Tangerang: Penerbit Pustaka Aufa Media (PAM Press), 2012), h. 8. 
Keberadaan koperasi Syariah harus menjadi solusi bagi berbagai permasalahan yang mucul di dalam bidang mu'amalah, baik itu masalah riba, ataupun masalah kesejahteraan masyarakat. Inilah yang akan diemban oleh koperasi Syariah Baitul Mu'min tugas untuk berperan dalam mengurangi praktik riba serta berperan dalam pengembangan kesejahteraan ummat, sehingga keberadaannya dapat menjadi solusi bagi segala permasalahan dalam mu'amalah. Berdasarkan hasil obsevasi bahwa koperasi Syariah Baitul Mu'min mempunyai peran yang signifikan, hal ini ditunjukkan dengan potensi jumlah jamaah yang menjadi anggota tetap terus meningkat setiap tahunnya, di samping itu peluang untuk memanfaatkan sarana dan prasarana terbuka lebar karena didukung oleh Sumber Daya Manusia yang proporsional. Namun semua peluang itu belum tergarap dengan baik hal ini salah satunya diakibatkan konsentrasi pengurus yang belum maksimal karena harus membagi waktu antara mengurus rumah tangga juga dalam waktu yang sama harus mengurus koperasi. Menarik untuk diteliti bagaimana upaya Koperasi Syariah Baitul Mu'min dalam mengatasi permasalahan tersebut.

\section{Koperasi Syariah}

Para ahli telah menjelaskan tentang pengertian koperasi Syariah, antara lain: ${ }^{4}$

a. Menurut Ahmad Ifham, pengertian koperasi syariah adalah usaha koperasi yang meliputi semua kegiatan usaha yang halal, baik, bermanfaat, serta menguntungkan dengan sistem bagi hasil, dan tidak mengandung riba.

b. Menurut Soemitra, arti koperasi syariah adalah suatu lembaga keuangan mikro yang dioperasikan dengan sistem bagi hasil, guna menumbuh-kembangkan usaha mikro dan kecil anggotanya sehingga mampu mengangkat derajat dan martabat serta membela kepentingan kaum fakir miskin.

\footnotetext{
${ }^{4}$ Gumelar Ardiansyah, Pengertian Koperasi Syariah, https:// guruakuntansi.co.id/koperasi-syariah/23/2/2020
}

c. Menurut Nur S. Buchori, pengertian koperasi syariah adalah jenis koperasi yang mensejahterakan ekonomi para anggotanya sesuai norma dan moral Islam dan berguna untuk menciptakan persaudaraan dan keadilan yang sesuai dengan prinsip-prinsip Islam.

d. Menurut Kementrian Koperasi UKM RI tahun 2009 pasal 1, koperasi syariah adalah suatu bentuk koperasi yang segala kegiatan usahanya bergerak di bidang pembiayaan, simpanan, sesuai dengan pola bagi hasil (Syariah), dan investasi.

Dari beberapa pengertian tersebut dirangkum bahwa koperasi syariah merupakan koperasi yang usaha-usahanya menerapkan prinsip-prinsip syariah. Maka apabila koperasi Syariah memiliki unit usaha produktif seperti simpan pinjam, maka koperasi syariah tidak dibenarkan berusaha dalam bidang-bidang yang mengandung unsur-unsur riba, maysir, dan gharar. Disamping itu, koperasi syariah boleh melakukan transaksi-transaksi yang merupakan keturunan-keturunan (derivative) dari unsurunsur tersebut sebagaimana juga berlaku bagi lembaga keuangan syariah lainnya.

Menurut Adil tujuan koperasi syariah adalah agar terjadi peningkatan kesejahteraan anggotanya dan kesejahteraan masyarakat dan turut serta membangun tingkat perekonomian Bangsa Indonsia berlandaskan syariah Islam. ${ }^{5}$ Sedangkan menurut Fachruddin sebagaimana dikutip Suhendi, tujuan koperasi dilihat dari segi fungsinya dapat dibagi menjadi tiga yaitu: Pertama. koperasi produksi, merupakan suatu koperasi yang memproduksi barang-barang yang bahan-bahannya berasal dari anggota koperasi; Kedua, koperasi konsumsi, merupakan suatu koperasi yang melakukan pembelian barang-barang untuk memenuhi kebutuhan para anggotanya; dan Ketiga. koperasi kredit, merupakan suatu koperasi yang memberikan pertolongan berupa dana usaha kepada anggotaanggotanya yang membutuhkan bantuan modal

${ }^{5}$ Adil, Bisnis Syariah di Indonesia, (Jakarta: Mitra Wacana Media, 2017), h. 90. 
dan untuk pelunasannya dengan cara dicicil. ${ }^{6}$ Sedangkan Menurut Dusuki dan Abdullah, tujuan koperasi syariah harus sesuai dengan Maqashid Syariah yang fungsinya adalah untuk melakukan dua hal penting, yaitu memberikan manfaat (manfaah) dan mencegah kerusakan atau cedera (madarrah). ${ }^{7}$

Menurut Nur S. Buchori tujuan koperasi syariah, yaitu: Pertama, mensejahterakan kondisi ekonomi anggotanya sesuai ajaran Islam; Kedua, menjalin persaudaraan dan menciptakan keadilan kepada anggotanya; Ketiga, pembagian hasil pendapatan dan kekayaan yang merata kepada semua anggotanya disesuaikan dengan tingkat kontribusinya; Keempat, kebebasan pribadi dalam kemaslahatan sosial; Kelima, meningkatkan kesejahteraan khususnya para anggotanya dan kesejahteraan masyarakat pada umumnya dan turut serta membangun tingkat perekonomian Bangsa berlandaskan syariah Islam. ${ }^{8}$

Di Indonesia mulai terbentuknya koperasi Syariah dilandasi oleh Keputusan Menteri (Kepmen) Nomor 91/Kep/MKUKM/IX/2004 tanggal 10 September 2004 tentang Petunjuk Pelaksanaan Kegiatan Usaha Koperasi Jasa Keuangan Syariah. Berlandaskan Alquran dan hadis, Pancasila dan Undang-Undang Dasar Tahun 1945.

\section{Usaha-usaha Koperasi Syariah}

Usaha koperasi syariah pada dasarnya mengikuti ketentuan dalam hukum Islam, sehingga dibatasi oleh aturan agama dan juga aturan pemerintah yang berlaku di Indonesia. Berikut syarat untuk menjalankan usaha koperasi syariah:

a. Usaha koperasi syariah meliputi semua kegiatan usaha yang halal, baik dan bermanfaat (thayyib) serta menguntungkan

${ }^{6}$ Hendi Suhendi Fiqih Muamalah, h. 293.

${ }^{7}$ Dusuki, A.W. and N.I. Abdullah, "Maqasid Al-Shariah, Maslahah, And Corporate Social Responsibility", American Journal of Islamic Social Sciences, Vol. 24, No. 1, 2007, h. 25.

8 Buchori, N.S., "Koperasi dalam Perspektif Ekonomi Syari'ah", Maslahah (Jurnal Hukum Islam dan Perbankan Syariah), Vol. 1, No.1, 2010, h. 93-115. dengan sistem bagi hasil dan tanpa riba, judi atau pun ketidakjelasan (gharrar).

b. Untuk menjalankan fungsi perannya, koperasi syariah menjalankan usaha sebagaimana tersebut dalam sertifikasi usaha koperasi.

c. Usaha-usaha yang diselenggarakan koperasi syariah harus sesuai dengan fatwa dan ketentuan Dewan Syariah Nasional Majelis Ulama Indonesia.

d. Usaha-usaha yang diselenggarakan koperasi syariah harus tidak bertentangan dengan peraturan perundang-undangan yang berlaku.

\section{Fungsi dan Peran Koperasi Syariah}

Menurut Adil fungsi dan peran koperasi syariah adalah sebagai berikut: ${ }^{9}$

a. Membangun dan mengembangkan potensi dan kemampuan anggota pada khususnya, dan masyarakat pada umumnya, guna meningkatkan kesejahteraan sosial ekonominya.

b. Memperkuat kualitas sumber daya insani anggota, agar menjadi lebih amanah, professional (fathanah), konsisten, dan konsekuen (istiqamah) di dalam menerapkan prinsip-prinsip ekonomi Islam dan prinsipprinsip Syariah Islam.

c. Berusaha untuk mewujudkan dan mengembangkan perekonomian nasional yang merupakan usaha bersama berdasarkan azas kekeluargaan dan demokrasi ekonomi.

d. Sebagai mediator antara menyandang dana dengan penggunan dana, sehingga tercapai optimalisasi pemanfaatan harta.

e. Menguatkan kelompok-kelompok anggota, sehingga mampu bekerjasama melakukan kontrol terhadap koperasi secara efektif.

f. Mengembangkan dan memperluas kesempatan kerja

g. Menumbuhkan-kembangkan usaha-usaha produktif anggota

${ }^{9}$ Adil, Bisnis Syariah..., h. 90. 


\section{Modal Awal Koperasi Syariah}

Dalam membentuk koperasi Syariah diperlukan adanya keberanian dan kesamaan visi dan misi di antara para pendiri. Selain itu, dalam mendirikan koperasi Syariah diperlukan perencanaan yang matang agar berjalan dengan baik. Koperasi Syariah juga hendaknya disahkan oleh notaris agar diakui keabsahannya. (Biaya pengesahan relative tidak begitu mahal, berkisar Rp. 300.000, tergantung wilayah hukumnya). ${ }^{10}$

Kita perlu memiliki modal awal ketika mendirikan koperasi Syariah. Modal ini dapat bersumber dari dana usaha yang dikumpulkan oleh koperasi. Dana ini dapat berasal dari dana sendiri yaitu berupa simpanan pokok, simpanan wajib, dana cadangan, dana hibah atau donasi. Dana usaha dapat pula berasal dari dana bantuan yang berasal dari lembaga lain seperti koperasi lain atau pun bank, serta dapat pula dananya berasal dari dana amanah seperti simpanan sukarela anggota dan lain sebagainya.

Sejalan dengan hal tersebut menurut Kasmir sumber dana merupakan hal yang sangat diperlukan bagi kelangsungan koperasi simpan pinjam dalam memenuhi segala kebutuhan para anggotanya yang membutuhkan bantuan dana atau modal usaha dan apabila memungkinkan koperasi juga dapat memberikanpinjaman dana kepada masyarakat luas selain anggotanya yang memerlukan bantuan dana. ${ }^{11}$

\section{Kegiatan Muamalah}

Menurut Mustofa muamalah adalah suatu aktivitas yang menyangkut hubungan antara manusia dengan manusia yang lain. Hal ini berbeda dengan hubungan antara manusia dengan Allah yang merupakan hubungan vertikal. Muamalah lebih kepada aktivitas sosial (horizontal) sehingga lebih longgar untuk dibentuk dan dikembangkan dengan adanya inovasi dalam transaksi dan produk. Sejalan dengan hal ini al-Ayatibi mengemukakanyang

${ }^{10}$ Adil, Bisnis Syariah..., h. 91.

${ }^{11}$ Kasmir, Bank dan Lembaga Keuangan Lainnya, (Jakarta: RajaGrapindo Persada, 2002), h. 271. dimaksud muamalah adalah interaksi dan komunikasi antar orang atau antar pihak dalam rangka beraktualisasi atau dalam rangka untuk memenuhi kebutuhan hidup seharihari. Muamalah merupakan kegiatan manusia dengan manusia lainnya yang berkaitan dengan harta dan aktivitas ekonomi atau bisnis dengan cara menggunakan akad, baik langsung maupun tidak langsung. ${ }^{12}$

Menurut Fahmi, dkk. pengertian muamalah merupakan pergaulan hidup dimana setiap orang melakukan perbuatan dengan orang lain yang menimbulkan hubungan hak dan kewajiban masing-masing. Kegiatan muamalah berkaitan dengan hubungan antara manusia dengan manusia lainnya. Pengertian secara sempit muamalah dapat diartikan aktivitas ekonomi yang berkaiatan dengan manajemen bisnis. Di antara faktor yang menentukan suksesnya manajemen dan bisnis adalah bagaimana pelaku bisnis dapat mengelola sumber daya manusia yang merupakan asset perusahaan. ${ }^{13}$

Dalam agama Islam harus terdapat keseimbangan antara mengurus urusan dunia dan urusan akhirat. Keseimbangan aspek dunia dan akhirat adalah karakteristik unik dalam sistem ekonomi Islam. Adanya perpaduan antara unsur materil dan spiritual ini tidak dapat dijumpai dalam sistem perekonomian lain, baik sosialis maupun kapitalis. Peran sistem sosialis sangat berharga dalam upaya pemerataan ekonomi. Begitupun peran sistem kapitalis tidak dapat diragukan lagi dalam mengefisienkan hasil produksi. Namun, sistem sosialis dan kapitalis tersebut telah mengabaikan pemenuhan kebutuhan manusia yang sangat penting yaitu dalam bidang spiritual. ${ }^{14}$ bermuamalah dalam ajaran islam bukan hanya menyangkut urusan duniawinya saja akan tetapi harus diperhatikan tata cara dan etikanya agar muamalah sesuai

\footnotetext{
${ }^{12}$ Imam Mustofa, Fiqh Muamalah Kontemporer. (Jakarta: PT. Raja GrafindoPersada), 2016. h. 6.

13 Fahmi, dkk., HRD Syariah Teori dan Implementasi, (Jakarta: Gramedia Pustaka Utama, 2014), h. 19-20.

${ }^{14}$ Muhammad Syafi'i Antinio, Bank Syariah dari Teori Ke Praktik, (Jakarta: Gema Insani, 2002), h. 13.
} 
dengan tuntunan Allah dan Rasul-Nya, sehingga bermuamalah menjadi bernilai ibadah.

Menurut Nurhadi, hikmah muamalah secara umum terealisasi dalam lima bentuk, yaitu: ${ }^{15}$

a. Mewujudkan ketundukan pada syariat Allah Swt dibuktikan dengan nilai-nilai ibadah dalam kegiatan muamalah iqtishadiyah sesuai syariah, dengan melakukan syirkah koperasi secara syariah.

b. Melestarikan dan menghidupkan sunah Rasul saw dengan cara mengikuti sunnah Rasul saw dalam bermuamalah Iqtishadiyah sesuai tuntunan-Nya, dengan cara berinteraksi ekonomi secara syirkah sebagai bentuk tolongmenolong antar sesame.

c. Menjaga diri dari yang diharamkan Allah dan Rasul-Nya dan mengambil serta menikmati yang dihalalkan-Nya, dengan cara bersyirkah sesuai tuntunan al-Qur'an dan sunah.

d. Menumbuh kembangkan moral (ahklaq mulia dan budi pekerti luhur yaitu sifat amanah, bijaksana, jujur, kesucian hati/ perasaan, dermawan dan sifat zuhud) dan materil (ketenangan dan keuntungan rezki halal berkah serta terjaga stabilitas ekonomi umat manusia).

e. Mewujudkan persaudaraan (ukhwah Islamiyah/ tolong menolong) dan persatuan (menjauhkan dari iri dengki, saling menzalimi, permusuhan, perselisihan serta pertengkaran).

\section{Masjid dan Aktivitas Ekonomi}

Masjid merupakan Lembaga dan pusat tumpuan umat Islam dalam konteks ibadah. Umat Islam juga dituntut untuk memakmurkan masjid dengan sebaiknya. Hubungan antara masjid dan pembangunan sosio-ekonomi umat Islam juga sangat erat. Sejarah awal Islam menunjukkan masjid berperan penting sebagai tempat mendirikan shalat Jum'at, shalat berjemaah, pusat kajian ilmu, pengumpulan dan

${ }^{15}$ Nurhadi, "Maqashid Koperasi Syariah", I-Economic, Vol. 4. No 2. Desember 2018, h. 174. pembagian harta rampasan perang, pengurusan wakaf, zakat, pengajian Alquran, mahkamah, pusat ekonomi, penetapan strategi peperangan dan sebagainya. ${ }^{16}$ Pada masa sekarang ini banyak umat islam yang menginginkan kembalinya masjid menjadi pusat kegiatan umat bukan hanya sebagai tempat ritual semata, melainkan menjadi pusat kekuatan ekonomi umat.

Kajian tentang ekonomi Islam banyak dilakukan oleh para ulama Islam sepanjang sejarah perkembangan Islam, terutama sampai abad ke-10 Hijriyah. Pada zaman tersebut kitab-kitab tentang ekonomi Islam (mu'amalah) sangat banyak. Dalam kitab-kitab fikih tidak pernah terlewatkan kajian tentang ekonomi Islam ataupun dalam pengajian-pengajian tentang ajaran Islam. Berbeda dengan keadaan di zaman sekarang dimana jarang sekali kajiankajian tentang ekonomi Islam dilakukan di masjid-masjid, sementara dimasa kejayaan Islam eksistensi keilmuan ekonomi sudah menjadi tradisi yang diterapkan dalam kehidupan. Maka kajian-kajian ekonomi Islam ini harus dihidupkan kembali di masjid-masjid supaya fungsi masjid sebagaimana zaman Rasulullah dapat diwujudkan kembali. ${ }^{17}$ Upaya yang dilakukan dapat berupa halaqah ataupun kajian ekonomi melalui metode dakwah, ataupun melalui pendirian lembaga yang bergerak dalam ekonomi Islam seperti koperasi Syariah berbasis masjid, dengan harapan menambah pengetahuan dan pemahaman para jamaah tentang ekonomi Islam sekaligus dalam rangka meningkatkan kesejahteraan ummat.

\section{Metode Penelitian}

Objek pada penelitian ini adalah Koperasi Syariah Baitul Mu'min atau disingkat KSBM. KSBM beralamat di Jalan Sekehaji RW 15, Komplek Pasir Jati, Desa Jati Endah Kecamatan

${ }^{16}$ Ahmad Raflis Che Omar, dkk., "Social Business Through Mosque Economic Activities", Journal of Global Business and Social Entrepreneurship (GBSE), Vol. 1, No.1, 2017, h. 39-46.

17 Dalmeri, "Revitalisasi Fungsi Masjid Sebagai Pusat Ekonomi Dan Dakwah Multikultural", Jurnal Walisongo, Vol. 22, Nomor 2, November 2014, h. 328. 
Cilengkrang Kabupaten Bandung Provinsi Jawa Barat.

Pendekatan yang digunakan dalam penelitian ini adalah pendekatan empiris yaitu berusaha memecahkan permasalahan yang muncul dalam pengelolaan koperasi Syariah dengan cara melakukan observasi atau melihat langsung ke lapangan. Adapun jenis penelitiannya adalah penelitian deskriptif, yang berusaha memecahkan masalah dengan diteliti dan menggambarkan atau menjabarkan keadaan nyata suatu objek penelitian yang terjadi pada saat ini di lapangan.

Data dalam penelitian ini bersumber dari data yang dikumpulkan dan diperoleh langsung di lokasi penelitian dan hasil wawancara yang merupakan data primer, selain itu juga bersumber dari data sekunder yang berupa bahan-bahan hukum yang terdiri dari bahan hukum primer dan bahan hukum sekunder. Untuk melengkapi data dalam penelitian ini menggunakan metode studi kepustakaan dengan analisa data dilakukan secara kualitatif. Sedangkan metode analisis data dilakukan dengan menggunakan logika deduktif, yaitu menarik kesimpulan dari hal yang bersifat umum menjadi kasus yang bersifat khusus.

\section{Profil Koperasi Syariah Baitul Mu'min (KSBM)}

KSBM didirikan pada tanggal 24 Desember 2015 dan berada dibawah naungan Dewan Kemakmuran Masjid (DKM) Masjid Baitul Mu'min Bandung. KSBM didirikan untuk mewujudkan misi DKM Baitul Mu'min yakni sebagai wadah bermuamalah jama'ah, yang terangkum dalam motto DKM Baitul Mu'min, yakni Makmur Masjidnya, Sejahtera Jama’ahnya. Berdirinya KSBM ini dilatarbelakangi akan kebutuhan jama'ah. Banyaknya rentenir yang beroperasi di lingkungan sekitar masjid tidak bisa diabaikan. Sementara banyak jama'ah yang terdesak dana untuk kepentingan sekolah anaknya, biaya kesehatannya dan lain-lain yang sering datang ke rentenir. Kenyataan inilah yang mendorong segenap pengurus DKM Baitul
Mu'min untuk membentuk sebuah koperasi Syariah yang dinamakan Koperasi Syariah Baitul Mu'min (KSBM). KSBM beralamat di Jalan Sekehaji RW 15, Komp. Pasir Jati, Desa Jati Endah Kecamatan Cilengkrang Kabupaten Bandung Provinsi Jawa Barat 40616. Telp./HP 085295091348.

Koperasi Syariah Baitul Mu'min yang berada di bawah manajemen Masjid Baitul Mu'min Komplek Pasir Jati Desa Jati Endah Kecamatan Cilengkrang Kabupaten Bandung didirikan bertujuan untuk meningkatkan persaudaraan dan mempererat tali silaturrahim di antara jama'ah masjid Baitul Mu'min pada khususnya dan masyarakat sekitar pada umumnya (AD \& ART KSBM, 2015). Sehingga koperasi ini bukan sekedar badan usaha namun lebih dari itu sebagai wasilah terjalinnya ukhuwah islamiah dan ukhuwah insaniah bagi masyarakat sekitar. Dengan kata lain koperasi syariah Baitul Mu'min sesuai dengan misinya mempunyai peran dalam meningkatkan ukhuwah Islamiyah, semangat gotong royong dan tolong menolong, serta meningkatkan kesejahteraan dan kemakmuran jamaah.

Untuk melihat perkembangan KSBM, dapat dilihat dari perkembangan jumlah anggota sehingga dapat dijadikan satu tolak ukur penilaian sehat tidaknya sebuah koperasi. Oleh sebab itu, pengurus KSBM mengapresiasi masyarakat yang berminat menjadi anggota dan berperan aktif dalam mengembangkan KSBM. Berikut ini adalah jumlah anggota yang tercatat sampai 2019.

Tabel 1. Perkembangan Jumlah Anggota KSBM

\begin{tabular}{cccc}
\hline \multirow{2}{*}{ Tahun } & \multicolumn{2}{c}{ Jumlah Anggota } & \multirow{2}{*}{ Jumlah } \\
\cline { 2 - 3 } & Laki-laki & Perempuan & \\
\hline 2016 & 35 & 133 & 168 \\
\hline 2017 & 56 & 213 & 270 \\
\hline 2018 & 89 & 317 & 406 \\
\hline 2019 & 89 & 325 & 414 \\
\hline
\end{tabular}

Sumber: KSBM 
Berdasarkan tabel jumlah anggota di atas, terlihat perkembangan yang sangat pesat dari tahun 2016 ke tahun 2017 meningkat sebesar 60,7\%, sedangkan dari tahun 2017 sampai 2018 mengalami peningkatan sebesar 50,3\%. Hal ini menunjukkan minat yang tinggi dari masyarakat untuk menjadi anggota KSBM sekaligus menunjukkan peran penting KSBM dalam mengajak jamaah untuk bermuamalah sesuai syariat Islam.

Selain dari jumlah anggota, kita bisa melihat juga perkembangan KSBM berdasarkan jumlah modal/kas berjalan dan SHU yang dihasilkan. Berikut adalah perkembangan KSBM dalam rentang waktu 3 Tahun dilihat dari jumlah modal/kas berjalan dan SHU yang dihasilkan.

Tabel 2. Perkembangan Jumlah Modal KSBM

\begin{tabular}{cccc}
\hline Tahun & $\begin{array}{c}\text { Jumlah } \\
\text { Anggota }\end{array}$ & $\begin{array}{c}\text { Jumlah } \\
\text { Modal/Kas }\end{array}$ & $\begin{array}{c}\text { Sisa Hasil } \\
\text { Usaha }\end{array}$ \\
\hline 2016 & 168 & 123.764 .884 & 27.797 .284 \\
\hline 2017 & 270 & 326.114 .232 & 43.627 .220 \\
\hline 2018 & 406 & 575.337 .062 & 87.291 .006 \\
\hline
\end{tabular}

Sumber: KSBM

Berdasarkan tabel di atas kita dapat melihat perkembangan modal yang sangat signifikan, dari Tahun 2016 sampai Tahun 2017 mengalami peningkatan modal berjalan sebesar 163,5\% sedangkan dari tahun 2017 sampai tahun 2018 meningkat sebesar 76,4\%. Hal ini menunjukkan kepercayaan anggota terhadap KSBM terus meningkat sehingga mereka semakin mantap untuk berinvestasi di KSBM. Kita juga dapat melihat dari sisa hasil usaha dari Tahun 2016 sampai 2017 peningkatan SHU mencapai 56,9 $\%$ dan dari Tahun 2017 sampai 2018 mengalami peningkatan yang pantastis mencapai 100,08 \%. $\mathrm{Hal}$ ini menunjukkan KSBM sangat berperan penting dalam mensejahterakan para anggotanya.

\section{Kegiatan Koperasi Syariah Baitul Mu'min (KSBM)}

Kegiatan usaha yang dilakukan KSBM seperti koperasi syariah pada umumnya, yaitu melayani berbagai transaksi dengan jamaah Masjid Baitul Mu'min serta masyarakat sekitar Komplek Pasir Jati Desa Jati Endah Kecamatan Cilengkrang Kabupaten Bandung. Transaksi yang terjadi meliputi penerimaan simpanan, jual beli, kerjasama mitra, dan jasa. Selain itu, KSBM dapat melayani kerjasama ataupun transaksi secara khusus. Hal tersebut semata-mata untuk melayani dan membantu masayarakat sekitar masjid berada. Sehingga sasaran utama programprogram KSBM adalah jamaah serta masyarakt sekitar masjid. Untuk lebih rincinya, berikut produk-produk yang disediakan oleh KSBM.

a. Simpanan anggota yang berupa simpanan pokok, simpanan wajib dan simpanan sukarela. Simpanan pokok dibayarkan hanya 1 (satu) kali oleh anggota yaitu pada saat pendaftaran menjadi anggota dengan nominal yang telah ditetapkan dan menggunakan akad musahamah. Simpanan wajib dibayarkan setiap bulan oleh anggota dengan nominal tertentu dan bersifat rutin. Seperti halnya simpanan pokok, simpanan wajib menggunakan akad musahamah. Sedangkan simpanan sukarela sifatnya tidak wajib, boleh atau tidak melakukan simpanan sesuai kemampuan dan nominalnya tidak ditentukan. Berbeda dengan simpanan pokok dan simpanan wajib, simpanan sukarela menggunakan akad mudharah mutlaqah.

b. Perniagaan sembako, melayani segenap kebutuhan pokok serta kebutuhan sehari-hari. Barang-barang disediakan di outlet KSBM, namun pembeli dapat pula memesan produk yang tidak tersedia di outlet. Pembayaran untuk transaksi ini bersifat cash namun bila menginginkan pembayaran tangguh dapat mengikuti mekanisme pembiayaan barang. Dalam perniagaan sembako atau barang kebutuhan ini, banyak diantara anggota yang membeli paket kebutuhan untuk setiap 1 (satu) bulan. Sehingga mereka mengedepankan KSBM daripada membeli dari swalayan atau tempat lainnya.

c. Pembiayaan barang, melayani kepada anggota 
yang memerlukan barang dengan cara diangsung sesuai kemampuan dan kesepakatan anggota. Setiap anggota berhak untuk mendapatkan barang-barang kebutuhan rumah tangga melalui pembiayaan dari KSBM. Caranyaadalah dengan mengajukan keKSBM jenis barang yang dibutuhkan. Pengurus KSBM akan menganalisa kebutuhan anggota tersebut dan menentukan harga penjualan KSBM. Setelah disepakati harganya, anggota bisa mengangsur sesuai kemampuan dan kesepakatan dengan pengurus.

d. Selain pembiayaan berupa barang, KSBM memberikan pembiayaan berupa pinjaman yang khusus diberikan kepada anggota aktif. Pinjaman tersebut ada 2 (dua), yaitu: Pinjaman non-profit. Pinjaman ini diberikan kepada anggota untuk keperluan yang bersifat non-produktif, seperti biaya sekolah, biaya berobat dan keperluan lainnya. Pinjaman ini dibebaskan dari jasa. Anggota yang melakukan pinjaman non profit ini cukup mengembalikan sejumlah dana yang dipinjamnya. Pinjaman profit atau Penyertaan Modal. Pinjaman ini diberikan kepada anggota yang memiliki usaha, namun terbentur modal usaha. System yang diterapkan dalam penyertaan modal adalah sistem bagi hasil. Untuk mendapatkan pinjaman profit maupun non profit, anggota bisa langsung menghubungi pengurus KSBM. Kemudian pengurus KSBM akan menganalisis sesuai kemampuan kas yang ada.

e. Unit layanan pulsa, pembayaran listrik, telpon, Pajak Bumi dan Bangunan (PBB), Perusahaan Daerah Air Minum (PDAM), Badan Penyelenggara Jaminan Sosial (BPJS), Online Shop, transfer antar bank, dan pembayaran serta tagihan lainnya;

f. Unit layanan 'Dapoer KSBM', melayani aqiqah, syukuran, khitanan, pernikahan, dan bentuk acara lainnya. Unit layanan ini menyediakan jasa katering untuk berbagai acara yang dikelola oleh jamaah yang memiliki keahlian memasak. Pengerjaan terkadang dilakukan di rumah masing- masing dengan pembagian menu tertentu sesuai pesanan.

g. Penyertaan modal, memberikan peluang kepada anggota yang memiliki usaha, namun ada keterbatasan modal. Selain itu, dapat pula anggota yang ingin merintis usahanya untuk memperoleh penyertaan modal serta pendampingan dari anggota yang lebih mapan atau lebih dahulu memiliki usaha. Biasanya sesama anggota bisa sharing pengalaman dan membantu pemasaran, bahkan bisa terlibat kerja sama lebih jauh.

h. Unit pelayanan jasa, melayani pelayanan jasa seperti perbaikan pompa air, mesin cuci, pengurusan pajak kendaraan bermotor, rental mobil, pengiriman paket, dan jasa khusus lainnya. Selain menggunakan sumber daya atau pegawai KSBM, pengadaan jasa ini dapat melibatkan anggota yang memiliki kemampuan tertentu untuk melayani jasa dari konsumen.

i. Kemitraan KSBM, yaitu bisa dengan menitipkan pemasarannya kepada KSBM dan pembagian keuntungannya dengan sistem bagi hasil. KSBM memiliki jaringan pemasaran yang cukup efektif untuk memasarkan segala jenis produk dari mitra. Dalam pengadaan barang ataupun produk, KSBM dapat bermitra dengan produsen ataupun distributor, yaitu bisa dari anggota ataupun non-anggota. Selain dilakukan dengan sistem jual beli, ada pula yang dilakukan melalui perjanjian konsinyasi dengan tetap mengedepankan prinsip bagi hasil yang saling menguntungkan.

\section{Analisis Peran Koperasi Syariah Baitul Mu'min (KSBM) Sebagai Pusat Kegiatan Muamalah Jamaah Masjid Baitul Mu'min.}

Berdasarkan hasil observasi pada KSBM terdapat beberapa poin mengenai operasional KSBM yang melibatkan jamaah Masjid Baitul Mu'min dalam kaitannya dengan kegiatan muamalah.

a. KSBM berdiri dan beroperasi di bawah naungan Masjid Baitul Mu'min serta digerakkan oleh dan untuk jamaah Masjid 
Baitul Mu'min. Aktif bergerak dengan mengusung semangat dan nilai-nilai yang tumbuh dari masjid, yaitu nilai-nilai yang bercorakkan syariah dan dorongan ibadah. Sehingga KSBM dapat menjadi salah satu solusi muamalah sesuai syariat Islam terutama bagi jamaah masjid. KSBM mendapatkan kepercayaan yang luar biasa dari jamaah untuk menjalankan muamalah sesuai syariat Islam sehingga terhindar dari praktek gharar dan riba karena keberadaannya di bawah pengawasan masjid juga jamaah.

b. KSBM memberikan berbagai pelayanan dengan menyediakan berbagai produk unggulan dalam memenuhi kebutuhan anggota dan masyarakat sekitar Komplek Pasir Jati Desa Jati Endah Kecamatan Cilengkrang Kabupaten Bandung. Prioritas produk memang ditujukan kepada anggota karena merujuk pada tujuan koperasi yang termaktub dalam Undang-undang Koperasi Nomor 25 tahun 1992 yaitu mensejahterakan para anggotanya. Sehingga anggota dapat mengakses seluruh produk KSBM tidak terkecuali. Produk-produk KSBM mayoritas lahir berdasar fungsi ekonomi untuk menghasilkan laba yang pada akhirnya kembali pada anggotanya. Produk-produk tersebut berupa: simpanan dan pembiayaan yang hanya bisa diakses oleh anggota koperasi, sedangkan seperti jual beli, jasa, dan kemitraan dapat diakses tidak hanya oleh anggota tapi juga oleh non-angggota

c. KSBM telah berkontribusi signifikan dalam meningkatkan ukhuwah Islamiyah, semangat gotong royong dan tolong menolong, serta meningkatkan kesejahteraan dan kemakmuran anggotanya. Nilai ukhuwah
Islamiyah ditunjukkan oleh anggota koperasi dengan saling menghormati dan menghargai serta menjaga silaturrahim antar anggota, jamaah, ataupun dengan masyarakt sekitar, bila ada yang sedang sakit atau tertimpa musibah, para anggota kooperasi banyak yang menjenguk. Semangat gotong royong dan tolong menolong nampak pada anggota kekompakkan mereka ketika akan melakukan kegiatan gotong royong baik dalam ruang lingkup kehidupan bermasyarakat ataupun dalam hal menjalankan bisnis dan operasional KSBM. Selain itu para anggota seringkali ikut membantu ataupun mendonasikan sebagian harta, tenaga, maupun doanya bagi kerabat, sesama anggota ataupun masyarakat sekitar yang tertimpa musibah. Sedangkan dalam hal meningkatkan kesejahteraan dan kemakmuran anggotanya, keberadaan KSBM telah mampu meningkatkan pendapatan anggotanya. Anggota KSBM banyak yang bisa secara mandiri membuka usaha atau mengembankan usahanya melalui program kemitraan atau melalui pembiayaan yang diperoleh. Selain ada bantuan dari sisi modal kerja dan investasi, banyak dari anggota yang terbantu berkat sharing pengalaman yang dilakukan antar sesama anggota. Bahkan tidak sedikit yang terbantu dengan bantuan secara langsung anggota yang mencarikan pasar. Ada pula yang menjual produknya di KSBM dan dapat dibeli anggota lainnya.

Berdasar analisis peran KSMB di atas, kiranya dapat dibuat sebuah model pengembangan koperasi syariah dalam kaitannya dengan kegiatan muamalah jamaah masjid. Berikut model yang dikembangakan dalam penelitian ini: 


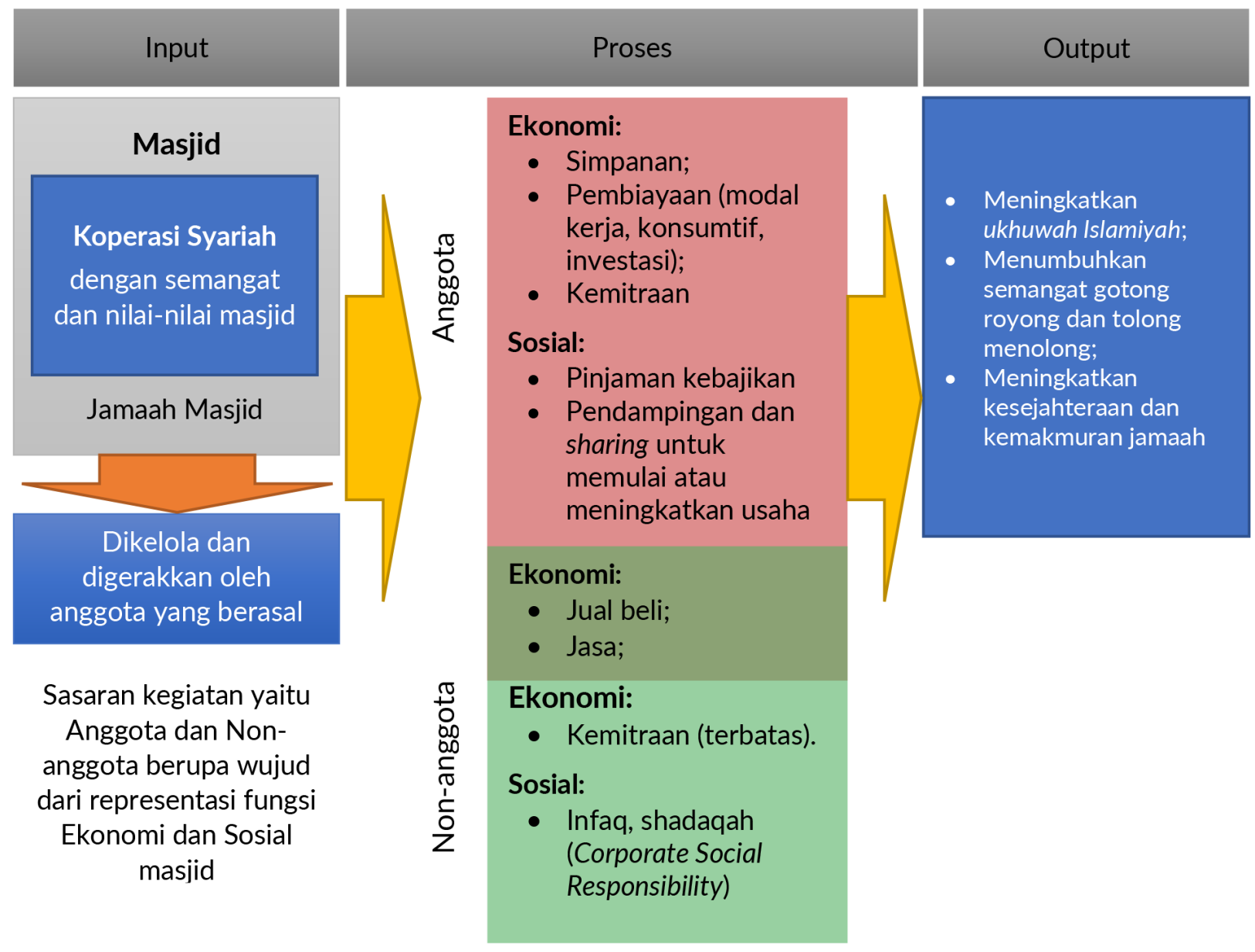

Gambar 1. Model Koperasi Syariah dalam Kegiatan Muamalah

Model tersebut dapat diterapkan bagi masjidmasjid lainnya dengan mendirikan koperasi syariah yang dikelola langsung dan diberdayakan oleh jamaah masjid. Sehingga keberadaan koperasi dapat memberikan kemandirian ekonomi bagi jamaah masjid. Dengan demikian koperasi Syariah Baitul Mu'min dapat diterapkan juga di masjidmasjid yang lainnya, dengan cara dan metode yang sama ataupun berbeda dengan yang dilaksanakan oleh pengurus masjid Baitul Mu'min, yang tujuannya adalah untuk memberdayakan masjid sebagai pusat ritual ibadah dan sekaligus pusat kegiatan ekonomi umat.

\section{Penutup}

Masjid memiliki peranan yang sangat penting bagi umat Islam. Selain tempat untuk melaksanakan ritual ibadah masjid juga mempunyai potensi sebagai tempat melakukan aktivitas ekonomi dalam rangka mensejahterakan umat Islam. Salah satu aktivitas ekonomi masjid adalah dengan didirikannya koperasi Syariah. Potensi koperasi syariah sangat besar untuk berkembang dan memberikan manfaat bagi para anggotanya sehingga menciptakan kemudahan bagi para anggota untuk mendapatkan kebutuhannya juga sebagai sarana untuk mensejahterakan anggotanya. Koperasi Syariah Baitul Mu'min telah banyak berkontribusi dan mempunyai peranan penting dalam praktek muamalah yang sesuai Syariah Islam sehingga dapat terhindar dari praktik riba dan juga berperan penting terhadap perkembangan perekonomian jamaah masjid Baitul Mủmin.

\section{Pustaka Acuan}

Adil, U. Bisnis Syariah di Indonesia, Hukum dan Aplikasinya, Jakarta: Mitra Wacana Media, 2017. 
Ahmad, Raflis Che Omar. "Social Business Through Mosque Economic Activities." Journal of Global Business and Social Entrepreneurship (GBSE), Vol. 1, No.1, 2017.

Alma, Buchari,Manajemen Bisnis Syariah, Bandung: Alpabeta, 2016.

Antonio, Muhammad Syafi'i. Bank Syariah dari Teori ke Praktek, Jakarta: Gema Insani, 2002.

Bahtiar, Edi.,"Mengembalikan Fungsi Masjid Sebagai Sentra Peradaban Umat Manusia." Empirik, Vol. 5, No.2, 2012.

Buchori, Nur S. Koperasi Syariah, Tangerang: Penerbit Pustaka Aufa Media (PAM Press), 2012.

Buchori, Nur S. "Koperasi dalam Perspektif Ekonomi Syari'ah." Maslahah (Jurnal Hukum Islam dan Perbankan Syariah), Vol. 1, No.1, 2010.

Dalmeri, "Revitalisasi Fungsi Masjid Sebagai Pusat Ekonomi Dan Dakwah Multikultural.” Jurnal Walisongo, Vol. 22, No. 2, 2014. Universitas Indraprasta PGRI Jakarta.

Dusuki, A.W. and N.I. Abdullah, "Maqasid alShariah, Maslahah, and Corporate Social Responsibility." American Journal of Islamic Social Sciences, Vol. 24, No.1, 2007.
Fahmi, Abu, dkk. HRD Syariah Teori dan Implementasi, Jakarta: PT. Gramedia Pustaka, 2014.

Fidlizan, M., Mohd Yahya, M.H., Azila, A.R., \& Fatimah Salwa, A.H.,"Persepsi Masyarakat Islam terhadap Ide Pendanaan Dana Masjid: Kajian di Perak." Sains Humanika, Vol. 2, No. 1, 2014.

Kasmir. Bank dan Lembaga Keuangan lainnya, Jakarta: PT. Raja Grafindo Persada, 2002

KSBM, Anggaran Dasar dan Anggaran Rumah Tangga Koperasi Syariah Baitul Mumin, 2015.

Mustofa, Imam. Fiqh Muamalah Kontemporer, Jakarta: PT. Raja Grafindo Persada, 2016.

Nurhadi. "Maqashid Koperasi Syariah." I-Economic, Vol. 4. No 2, 2018.

Sholihin. Ahmad Ifham,Buku Pintar Ekonomi Syariah, Jakarta: Gramedia Pustaka Utama, 2010.

Soemitra, Andri. Bank dan Lembaga Keuangan Syariah, Jakarta: Prenada Media, 2010.

Suhendi, Hendi. Fiqih Muamalah, Jakarta: RajaGrafindo Persada, 2002. 